\title{
Study on In Vitro Growth of Rubus fraxinifolius Mutant (m1) Resulted from Gamma-Ray Irradiation $\left({ }^{60} \mathrm{Co}\right)$
}

\author{
DOI: 10.18196/pt.2018.082.70-76
}

\author{
Lily Ismaini*, Suluh Normasiwi, Muhammad Imam Surya, Destri \\ Center for Plant Conservation Botanic Gardens - Indonesian Institute of Science (LIPI) \\ Jl. Kebun Raya Cibodas, Sindanglaya PO. Box 19 Cipanas - Cianjur, 43253 Jawa Barat, Indonesia. Telp/fax: 0263-520448/0263-512233 \\ ${ }^{*}$ Corresponding author, email: lily.ismaini@lipi.go.id
}

\begin{abstract}
Rubus fraxinifolius belonging to the wild raspberry group has not been developed in Indonesia. Mutation breeding using gamma-ray as mutagen which was combined with in vitro culture is one of acceleration effort to obtain superior characteristics of the fruit crops, such as larger fruit size, higher nutrition content, plant with less of spines and fruit storage ability. The $R$. fraxinifolius seeds were irradiated with different doses of gamma-ray ranging from 0 to $500 \mathrm{Cy}$ using the ${ }^{60} \mathrm{Co}$ (Cobalt). This research aimed to determine in vitro growth of R. fraxinifolius mutant (M1) after irradiation using gamma-ray. The results showed that the highest percentage of seed germination was obtained on the doses of 100 and 200 Gy. Furthermore, the subculture of $R$. fraxinifolius mutant (M1) on MS medium with the addition of BA showed the different growth on number of shoots, number of leaves, and plantlet height. Moreover, R. fraxinifolius control showed higher value of shoots, number of leaves, and plantlet height at 4 and 8 weeks after subculture compared to R. fraxinifolius mutant. MS medium with the addition of IBA showed that the number of roots of $R$. fraxinifolius control (5.75) was higher than that of $R$. fraxinifolius mutant (M1) (4.83).

Keywords: In vitro, Mutant, Gamma-ray, Rubus fraxinifolius
\end{abstract}

\section{ABSTRAK}

Rubus fraxinifolius merupakan kelompok buah raspberry liar yang belum banyak dikembangkan di Indonesia. Pemuliaan mutasi menggunakan mutagen sinar gamma yang dikombinasikan dengan kultur in vitro merupakan salah satu upaya percepatan untuk memperoleh karakter tanaman buah yang unggul, yaitu ukuran buah besar, kandungan nutrisi tinggi, morfologi tanaman yang memiliki duri lebih sedikit, dan meningkatkan daya simpan. Biji $R$. fraxinifolius di radiasi dengan sinar gamma pada rentang dosis 0 sampai dengan 500 Gy yang bersumber dari ${ }^{60} \mathrm{Co}$ (Cobalt). Penelitian ini ditujukan untuk mengetahui pertumbuhan tanaman mutan generasi pertama (M1) R. fraxinifolius hasil iradiasi gamma secara in vitro. Hasil penelitian menunjukkan bahwa biji dengan dosis radiasi 100 dan 200 Gy menghasilkan persentase kecambah tertinggi yaitu mencapai 100\%. Setelah proses subkultur M1 pada media MS dengan penambahan hormon BA, terlihat bahwa perbedaan pertumbuhan M1 R. fraxinifolius terjadi pada parameter jumlah tunas, jumlah daun dan tinggi plantlet Pada 4 dan 8 minggu setelah subkultur rerata jumlah tunas, jumlah daun dan tinggi plantlet tanaman kontrol lebih tinggi dibandingkan dengan tanaman mutan. Pada tanaman kontrol 4 dan 8 minggu setelah subkultur menghasilkan jumlah tunas (1,5 dan 10), jumlah daun (8 dan 11), dan tinggi planlet (1,3 dan 2,54 cm), sedangkan pada tanaman mutan M1 menghasilkan jumlah tunas (2 dan 8), jumlah daun (5,75 dan 8,25), dan tinggi planlet (1,07 dan 2,7 cm). Untuk inisiasi akar pada media MS dengan hormon IBA, tanaman kontrol menghasilkan rata-rata jumlah akar yang lebih banyak dibanding tanaman mutan M1, yaitu sebanyak 5,75, sedangkan pada tanaman mutan M1 sebanyak 4,83.

Kata Kunci: In vitro, Mutan, Sinar gamma, Rubus fraxinifolius

\section{INTRODUCTION}

Rubus fraxinifolius is a type of wild raspberry a fruit commodity is one of the important factors fruit that grows in Indonesia's mountain forests. to develop $R$. fraxinifolius which is a native species Kalkman (1993) reported that $R$. fraxinifolius was spread on the islands of Kalimantan, Java, Sulawesi, Maluku, Bali, and Nusa Tenggara, starting from the of Indonesia through plant breeding programs. lowland to an altitude of $2500 \mathrm{~m}$ above sea level. According to the research conducted by Surya et al. (2018), R. fraxinifolius fruit has a high vitamin At present, the utilization and development of $R$. C content of $83.65 \mathrm{mg} / 100 \mathrm{~g}$, total carbohydrates fraxinifolius fruit still very limited. Surya (2009) of $11.48 \%$, the sugar content of $5.05 \mathrm{~g}$, the fiber reported that $R$. fraxinifolius fresh fruit has begun to be used and commercialized by the community, content of $6.43 \%$, and calorific value of 45.92 calories. The content of vitamin $\mathrm{C}$ and sugar in especially in the Cibodas area. Its high potential as $R$. fraxinifolius is higher than that of other types of rubus (Rubus rosifolius, Rubus chrysophyllus, Rubus 
pyrofolius, and Rubus idaeus (raspberry) (USDA, 2014; Surya et al., 2018).

Breeding of rubus plants is an effort to improve the genetic condition of plants to improve the quality of fruit producing rubus plants with large fruit size, high nutritional content, fewer spines, longer shelf life, and resistance to pests and diseases so that the economic value of the commodity becomes higher. One way to increase the genetic diversity of plants is through mutations with gamma-rays. Gamma-rays are high electromagnetic radiation that can induce genetic changes in plants (Astutik, 2012), damage and modify important components in cells and give different effects on morphology, anatomy, biochemistry, and physiology of plants, depending on the radiation dose given (Ashraf et al., 2003; Anggraito and Pukan, 2015).

In vitro culture is a method of planting parts of plants (protoplasts, cells, tissues, or organs) aseptically in bottles to form perfect plants or produce certain metabolite products (Hussain et al., 2012). Mutation breeding combined with tissue culture techniques is the best approach. Application of mutation induction in explants can result in mutations in somatic cells that will produce a wide variety of plants produced during in vitro culture (Hwang and Ko, 1988; Ishak, 2000).

Chemical mutagens and radiation can be used to induce mutations in higher plants. Gamma-ray treatment in plants can induce changes in genetic, cytological, biochemical, and physiological properties in cell tissues (Gunckel and Sparrow, 2001). According to Colbert and de Oliveira (1990), the hybridization process in rubus plants has many obstacles, this is because the incompatibility between species is relatively high so it is difficult to get diversity in the population for breeding. Mutation breeding activities using gamma-ray mutagen combined with in vitro culture is one of the efforts to accelerate the process to obtain the diversity and better character of $R$. fraxinifolius plants. This study aimed to determine the growth of $R$. fraxinifolius M1 from gamma-ray irradiation in vitro.

\section{MATERIALS AND METHODS}

The research was conducted in Tissue Culture Laboratory Center for Plant Conservation Botanic Gardens, Indonesian Institute of Science (LIPI) and Application Center for Isotope and Radiation Technology, National Nuclear Power Agency (BATAN).

\section{Seed Mutation and Seed Initiation by In Vitro}

Rubus fraxinifolius seeds were obtained from the fruit of $R$. fraxinifolius which had been grown and harvested in Cibodas Botanical Garden. The seeds were cleaned from fruit and dried. Irradiation was done on seeds that have been dry and clean. The process of irradiation using gamma-rays was carried out at a dose level of 0 (control), 100, 200, 300, 400, and $500 \mathrm{~Gy}$. After the irradiation process, the seeds were planted in vitro using MS media. A total of 25 seeds of $R$. fraxinifolius were planted in each culture bottle with 10 replications. In vitro sterilization and seed planting processes referred to Ismaini et al. (2017) using detergents, Tween 80, fungicides, bactericides, $70 \%$ alcohol, $\mathrm{NaOCl}$, and distilled water. The planting medium used was MSO. The percentage of seed germination or seed viability was used to determine the response of $R$. fraxinifolius seeds to gamma-rays. The subculture process was carried out on seeds that have germinated.

\section{Subculture: Shoots and Roots Initiation}

The planting medium used in the subculture process for multiplication of shoots was a combination of MS (Murashige and Skoog) media with a growth regulator BA (Benzyl Adenine). The use of BA on MS media was divided into three groups, namely MS + BA1 $(1 \mathrm{mg} / \mathrm{L}), \mathrm{MS}+\mathrm{BA} 2(2 \mathrm{mg} / \mathrm{L})$, and $\mathrm{MS}+\mathrm{BA} 3(3 \mathrm{mg} / \mathrm{L})$. Post subculture growth 
observations included the number of shoots, number of leaves, and plantet height. The subculture was then carried out for the rooting process on MS without hormones (MSO) and on MS added with IBA hormone with a concentration of $1 \mathrm{mg} / \mathrm{L}$ and $2 \mathrm{mg} / \mathrm{L}$. Growth observation was carried out at 8 weeks after subculture by counting the number of roots.

\section{RESULTS AND DISCUSSION}

Percentage of seed viability

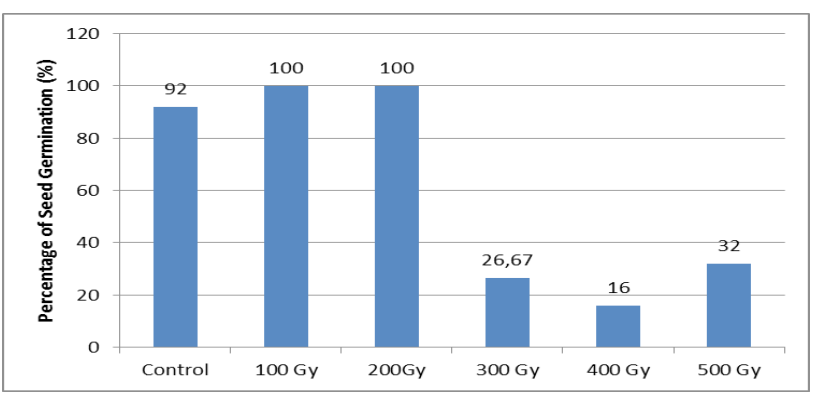

Figure 1. Percentage of Seed Germination of Rubus fraxinifolius First Generation Plants (M1)
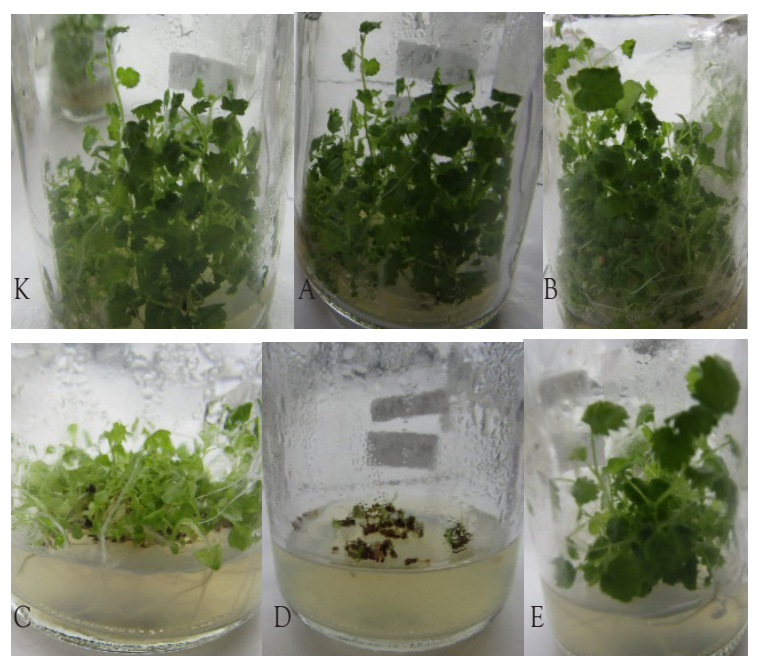

Figure 2. Seed Germination In Vitro of $R$. fraxinifolius (K: Control, A: 100 Gy, B: 200 Gy, C: 300 Gy, D: 400 Gy, E: 500 Gy)

Based on the results of germinations observations, it was found that gamma-ray irradiation affected the germination percentage of $R$. fraxinifolius seeds. The highest percentage of seed germination was observed in irradiated seeds with doses of 100 and 200 Gy (Figure 1). These results indicated that irradiation at doses of 100 and 200 Gy increased the percentage of seed germination of $R$. fraxinifolius M1 to reach $100 \%$. However, at doses of 300, 400, and 500 Gy, gamma-ray irradiation reduced the percentage of seed germination of $R$. fraxinifolius M1 (Figure 2). This result was in line with research from Giovani et al. (2015) who reported that gammaray irradiation at doses 50, 100, and 200 Gy could increase Rosa hybrid seed germination. In addition, Surya et al. (2016) also reported that the increase of seed germination occurred in Rubus chrysophyllus and Rubus lineatus after gamma-rays irradiation.

\section{Shoot Initiation}

Rubus fraxinifolius M1 seeds which had germinated then were sub-cultured for the rooting process on MS media with three variations of cytokinin growth regulators. Observation of $R$. fraxinifolius $\mathrm{M} 1$ growth after subculture was carried out at 4 and 8 weeks after the subculture process (Table 1). The results showed that there were no significant differences in the number of shoots at 4 weeks after subculture. At 4 weeks after the subculture, differences in growth occurred in the number of leaves and plantet height parameters. Table 1 showed that the average number of leaves and height of control plantlets were higher than the mutants. In observation at 4 and 8 weeks after the subculture, control plants produced 1.5 and 10 shoots, 8 and 11 leaves, and plantlets with height of 1.3 and $2.54 \mathrm{~cm}$, respectively. Meanwhile, mutant plants M1 produced 2 and 8 shoots, 5.75 and 8.25 leaves, and plantlets with height of 1.07 and 2.7 $\mathrm{cm}$, consecutively.

The study of peanut plants and handeleums irradiated by gamma rays showed a decrease in the growth parameters of plants treated with mutations. The higher the irradiation dose given causes 
the number of leaves to decrease. This case occurs because gamma-rays produce free radicals that can damage cellular meristem plants and inhibit DNA synthesis, thus disrupting and affecting plant morphology, anatomy, and biochemistry (Lukanda et al. 2013, Rosmala et al. 2015). In the study of Jan et al. (2011), low doses of gamma irradiation significantly increased vegetative growth, while high doses had been shown to inhibit the growth of the medicinal plant Psoralea corylifolia. Low-dose gamma-ray irradiation generally results in stimulation effects on germination through increased enzyme activity, improvement of respiration cells, and increased production of reproductive structures (Luckey 1998). On the other hand, gamma-ray irradiation in high doses generally results in effect as an inhibitor on germination (Kumari and Singh 1996), decreased auxin levels or chromosomal damage (Sparrow 1962). According to Luckey (2003), the effect of this change is known as the hormesis phenomenon which is interpreted as stimulation at low doses of ionization and inhibition at high doses.

Table 1. The Average Growth of Rubus fraxinifolius Mutants (M1) After Subculture

\begin{tabular}{|c|c|c|c|c|c|c|c|}
\hline \multirow{2}{*}{\multicolumn{2}{|c|}{ Treatment }} & \multicolumn{3}{|c|}{4 weeks after subculture } & \multicolumn{3}{|c|}{8 weeks after subculture } \\
\hline & & \multirow{2}{*}{$\frac{\text { Number of shoots }}{1.00 \mathrm{a}}$} & \multirow{2}{*}{$\frac{\text { Number of leaves }}{6.00 \mathrm{ab}}$} & \multirow{2}{*}{$\begin{array}{c}\text { Plantlet's height } \\
1.10 \mathrm{ab}\end{array}$} & \multirow{2}{*}{$\frac{\text { Number of shoots }}{3.00 \text { cde }}$} & \multirow{2}{*}{$\frac{\text { Number of leaves }}{11.00 \mathrm{a}}$} & \multirow{2}{*}{$\frac{\text { Plantlet's height }}{2.54 \mathrm{ab}}$} \\
\hline Control & BA 1 & & & & & & \\
\hline & BA 2 & $1.50 \mathrm{a}$ & $8.00 \mathrm{a}$ & $1.30 \mathrm{a}$ & $10.00 \mathrm{a}$ & $7.50 \mathrm{bcd}$ & $1.82 \mathrm{abc}$ \\
\hline & BA 3 & $1.00 \mathrm{a}$ & $4.50 \mathrm{bc}$ & $0.90 a b c$ & $2.00 \mathrm{de}$ & $9.00 \mathrm{ab}$ & $2.18 a b$ \\
\hline \multirow[t]{3}{*}{200 Gy } & BA 1 & $1.83 \mathrm{a}$ & $4.83 \mathrm{bc}$ & $0.97 a b$ & $5.00 \mathrm{bcd}$ & $8.20 \mathrm{~b}$ & $2.54 a b$ \\
\hline & BA 2 & $2.00 \mathrm{a}$ & $3.86 b c$ & $0.86 a b c$ & $5.00 \mathrm{bcd}$ & $6.60 \mathrm{cde}$ & $1.82 \mathrm{abc}$ \\
\hline & BA 3 & $1.83 \mathrm{a}$ & $5.67 \mathrm{~b}$ & $1.07 a b$ & $6.20 a b c$ & $7.20 \mathrm{bcd}$ & $2.18 a b$ \\
\hline \multirow[t]{3}{*}{300 Gy } & BA 1 & $1.83 \mathrm{a}$ & $5.00 \mathrm{bc}$ & $0.82 b c$ & $2.25 \mathrm{de}$ & $6.25 \mathrm{de}$ & $1.13 b c$ \\
\hline & BA 2 & $1.60 \mathrm{a}$ & $3.80 c$ & $0.82 b c$ & 3.25 cde & $8.00 \mathrm{bc}$ & $1.55 \mathrm{abc}$ \\
\hline & BA 3 & $1.67 \mathrm{a}$ & $4.50 \mathrm{bc}$ & $0.78 \mathrm{bc}$ & $6.00 \mathrm{abc}$ & $8.00 \mathrm{bc}$ & $2.32 \mathrm{ab}$ \\
\hline \multirow[t]{3}{*}{400 Gy } & BA 1 & $1.83 \mathrm{a}$ & $4.17 \mathrm{bc}$ & $0.60 c$ & $1.00 \mathrm{e}$ & $6.00 \mathrm{de}$ & $0.50 c$ \\
\hline & BA 2 & $1.33 a$ & $5.00 \mathrm{bc}$ & $0.72 b c$ & 4.50 bcde & $8.25 b$ & $1.83 \mathrm{abc}$ \\
\hline & BA 3 & $1.67 \mathrm{a}$ & $4.67 \mathrm{bc}$ & $0.67 c$ & $5.33 \mathrm{bcd}$ & $4.90 \mathrm{e}$ & $2.83 a$ \\
\hline \multirow[t]{2}{*}{$500 \mathrm{~Gy}$} & BA 2 & $1.25 \mathrm{a}$ & $5.75 b$ & $0.65 c$ & $6.00 \mathrm{abc}$ & 7.00 bcde & $1.80 \mathrm{abc}$ \\
\hline & BA 3 & $1.83 \mathrm{a}$ & $5.33 \mathrm{~b}$ & $0.97 \mathrm{ab}$ & $8.00 a b$ & $5.00 \mathrm{e}$ & $2.70 \mathrm{ab}$ \\
\hline
\end{tabular}

Note: Seeds irradiated at 100Gy experienced contamination during the subculture process; numbers followed by the same lowcase letters in the same column are not significantly different according to LSD test at $5 \%$.
Dose determination of gamma irradiation is an important factor in artificial mutations and adapted to the plant material used. At a tolerable range, gamma-ray irradiation can cause mutations in cells that will appear in the phenotypic appearance of plants. High or low doses of gamma irradiation that affect changes in plant properties differ depending on the type of plant used.

The use of growth regulators in tissue culture depends on the type of plant. Lestari (2011) reported that cytokinin (BA) growth regulators were generally used for the formation or multiplication of shoots. The formation of new shoots from mutation breeding activities combined with in vitro culture is very important. When breeding activities are intended to improve one or more characters of a cultivar, and do not expect variation, the appropriate method is mutation and multiplication in vitro through the axillary buds (Predieri, 2001). In this study, it can be seen that at 8 weeks after the subculture, MS + BA3 media gave significant effect on the growth of $R$. fraxinifolius mutant (Table 1). 


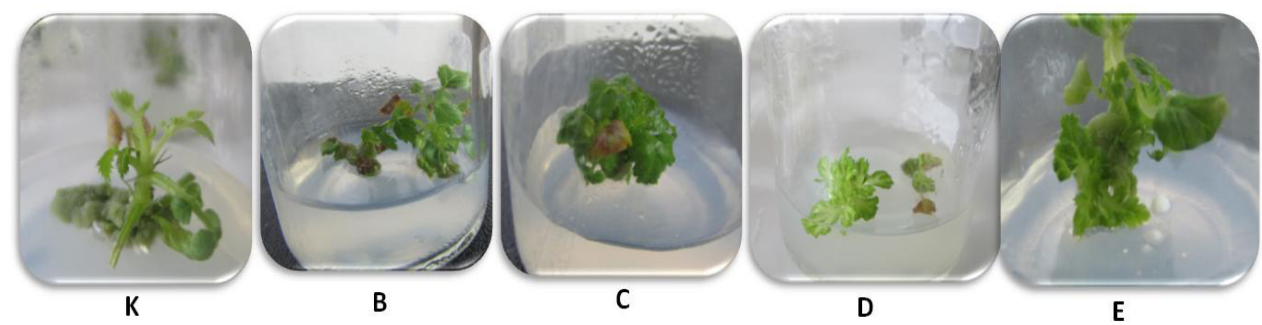

Figure 3. Variation of Rubus fraxinifolius mutant (M1) Growth In Vitro (K: Control, B: 200 gy, C: 300 gy, D: 400 gy, E: 500 gy)

Observation on phenotypic variation of $R$. part of the plant, especially the part where the cell fraxinifolius plant mutant growth was carried out is actively dividing (Micke and Donini, 1993). In in this experiment. Seen in Figure 3, the visual observations of $R$. fraxinifolius showed there were unique forms (khimera) caused by the treatment of gamma-ray mutations. One of the morphological changes was the variation in the shape of the plantlet leaves and stems. When compared with control plantlets, plants treated with gamma-ray irradiation had abnormal leaf shape, wavy or not symmetrical, the stem was short and wide. Plantlet irradiated with 300 Gy gamma-ray showed rosette shape with very short stems and leaves accumulated at one growing point. While in 500 Gy gammarays, the growth was greater than the control, the leaves were wider and the stems were larger. However, like plants that have mutations in general, the forms of khimera caused by these mutations did not have specific characteristics and did not occur simultaneously in all plants treated. In the study conducted by Royani et al. (2012), a spiral leaf shape on green chirayta medicinal plants was obtained from gamma cobalt 60 irradiation. In another study conducted by Devy and Sastra (2006), rosette shoots and critical leaves on ginger plants were produced by gamma irradiation. According to Kurniati (2004), the variation of leaf forms in Phalaenopsis orchids arised as a result of mutant cell abnormalities that develop into different tissues and organs of the origin cell.

Mutations are genetic changes, either changes in a single gene, a number of genes, or chromosome arrangements. These changes can occur in every general, mutations are produced by all types of genetic changes that result in decreased phenotypic changes, including chromosomal diversity, causing genetic diversity (Soeranto, 2003). In mutation breeding activities, Yunita (2009) reported that a combination of in vitro culture and physical mutagen is a variety of effective and efficient varieties. The diversity caused by somaclonal variation and mutation induction is random.

Mutation breeding, one of them with gammarays, in forest woody plants that have not been widely cultivated has the potential to produce new diversity in species that have relatively low species diversity or to obtain plant characteristics that are more adaptive to changes in the environment with high levels of productivity (Zanzibar and Sudrajat 2013).

\section{Roots Initiation}

Based on the results of the subculture, application of IBA hormone to $R$. fraxinifolius could increase the average number of roots on in vitro culture plants. However, the administration of IBA hormone did not significantly influence the increase in the number of roots of mutant plants. Figure 4 showed that $R$. fraxinifolius control explants grown on MSO media produced an average number of roots as many as 3.25, whereas in MS media given IBA hormone $1 \mathrm{mg} / \mathrm{L}$ and IBA $2 \mathrm{mg} / \mathrm{L}$ the average number of roots increased to be 5.75 and 5.67. In $R$. fraxinifolius mutant explants, the average number of 


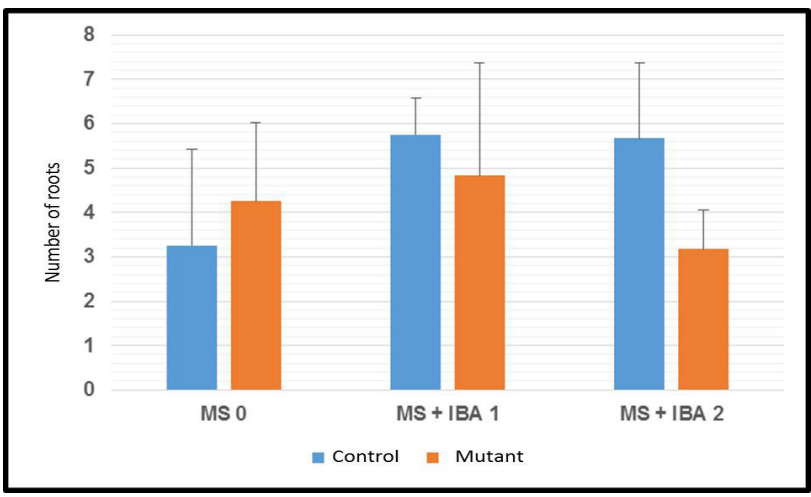

Figure 4. The Influence of Media on The Growth of Root In Rubus fraxinifolius Mutant Grown In Vitro Culture

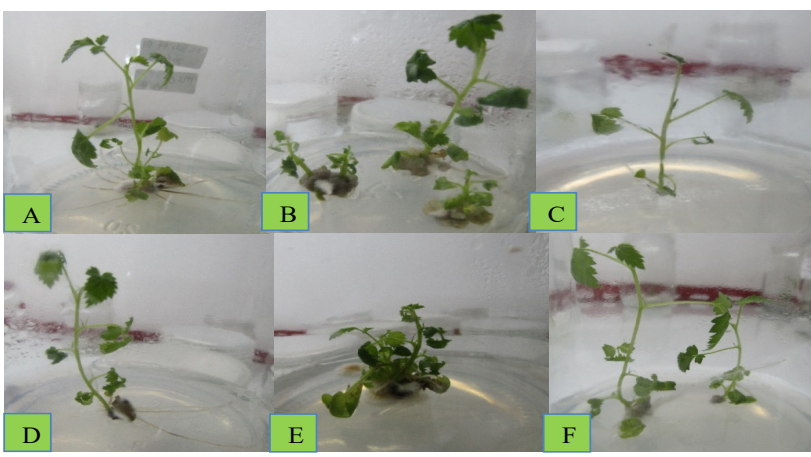

Figure 5. Root Initiation on R. fraxinifolius Mutant Plants (above): A. MSO medium, B. MS + IBA $1 \mathrm{mg} / \mathrm{L}, \mathrm{C} . \mathrm{MS}+\mathrm{IBA}$ $2 \mathrm{mg} / \mathrm{L}$; Root Initiation on $R$. fraxinifolius Control Plants (bottom): D. MSO, E. MS + IBA $1 \mathrm{mg} / \mathrm{L}, \mathrm{F} . \mathrm{MS}+\mathrm{IBA} 2 \mathrm{mg} / \mathrm{L}$

roots produced on the hormone without hormone (MSO) was 4.25, while the addition of IBA $1 \mathrm{mg} / \mathrm{L}$ and IBA $2 \mathrm{mg} / \mathrm{L}$ produced an average number of roots of 4.83 and 3.17 (Figure 5). Furthermore, from Figure 4, the number of roots of mutant plants was less than that of control plants. This may be due to a disturbance of auxin activity. According to Devy and Sastra (2006), the occurrence of root growth inhibition on ginger plants resulting from gamma irradiation was due to the disruption of endogenous auxin activity that occurs after the irradiation process so that the concentration of endogenous auxin was reduced and the roots were not formed. Auxin has a dual role depending on the chemical structure, concentration, and tissue of the treated plant. Auxin is generally used to induce callus formation, suspension culture, and lateral root initiation and gravitational force response (Wattimena, 1992; Chun et al., 2003; Lestari, 2011)

\section{CONCLUSION}

Treatment of gamma irradiation gave an effect on germination and growth of $R$. fraxinifolius grown in vitro culture. The results showed that seeds with irradiation dose of 100 and 200 Gray produced the highest percentage of germination. Low-dose treatments stimulated plant growth, while higher doses of irradiation given affected plants as inhibitors of germination and growth parameters. After the M1 subculture process on MS media with the addition of BA hormone, it was seen that the difference in R. Fraxinifolius M1 growth occurred in the the number of shoots, number of leaves, and plantlet height. Similarly, the M1 subculture on the MS medium with the addition of the IBA hormone in $R$. fraxinifolius could increase the average number of roots on in vitro culture plants.

\section{ACKNOWLEDGEMENTS}

The author expressed their gratitude to the Cibodas Botanical Garden Plant Conservation Center, Indonesian Institute of Science (LIPI) which has financed and supported this research activity through 2015 Thematic DIPA funding.

\section{REFERENCES}

Anggraito, Y.U, and Pukan, K.K. 2015. Perubahan Karakter Kuantitatif Mucuna Pruriens Generasi M1 Pasca Irradiasi Sinar Gamma Co-60. Sainteknol: Jurnal Sains dan Teknologi, 13 (1): 79-86

Ashraf, M., Cheema, A.A., Rasheed, M., and Qamar, Z. 2003. Effect of Gamma Rays on M1 Generation in Basmati Rice. Pak J Bot, 35 (5): 791-795

Astutik. 2012. Keragaman Klon Phalaenopsis Hasil Radiasi Sinar Gamma: Perubahan Fenotif Fase Pertumbuhan Vegetative. Buana Sains, 12 (1): 37-42

Colbert, S., and de Oliveira, D. 1990. Influence of Pollen Variety on Raspberry Development.Journal of Heredity, 81 (6) :434-437

Chun, T., S. Taketa, S. Tsurumi dan M. Ichii. 2003. The effects of auxin on lateral root initiation and root gravitropism in a lateral rootless mutant Lrt1 of rice (Oryza sativa L.). Plant Growth Regulation, 39 (2): 161-170

Devy, L., and D.R. Sastra. 2006. Pengaruh Radiasi Sinar Gamma 
Terhadap Kultur In Vitro Tanaman Jahe. J. Sains dan Teknologi Indonesia, 8(1): 7-14

Giovani, A., Scariot, V., Caser, M., Buttafava, A., Mansuino, A., Ghione, G.G., Savona, M., Sabatini, M.E., Carbonera, D., and Balestrazzi, A.2015. Mutation breeding using gamma rays to increase seed germination in Rosa hybrid. Acta Hortic, 1087: 373-378

Gunckel, J.E., and Sparrow, A.H. 2001. Ionizing Radiation: Biochemical, Physiological and Morphological Aspect of Their Effects on Plants (In: External Factors Affecting Growth and Development, Georg, M. Ed. Springer-Verlag, Berlin

Hussain, A., Nazir, H., Ullah, I., and Qarshi, I.A. 2012. Plant tissue culture: current status and opportunities. Recent Advances in Plant in vitro Culture (1-28). London Bridge Street, London: INTECH Open Access Publisher

Hwang, S.C., and Ko, W.H. 1988. Mutants of Cavendish Banana Resistance to Race 4 of Fusarium oxysporum f.sp. cubuse. Plant Prot. Bull, 30: 36-392

Ishak. 2000. Improvement of banana quality through infuced mutation. Paper presented in Seminar of Methodology for plant Mutation Breeding Screening for Quality. Jakarta

Ismaini, L., Surya, M.I., dan Destri. 2017. In vitro plant regeneration from hypocotyl of Arben (Rubus fraxinifolius Poir.). Australian Journal of Crop Science, 11 (04): 474-478

Jan, S., Parween,T., Siddiqi, T.0., and Mahmooduzzafar. 2011. Gamma Radiation Effect on Growth and Yield Attributes of Psoralea corylifolia L. with Reference to Enhanced Production of Psoralen. Plant Growth Regulation, 64 (2): 163 - 171

Kalkman, C. 1993. Rosaceae, Flora Malesiana ser.l, 11(2). Leiden University

Kumari, R., and Singh, Y. 1996. Effect of Gamma Rays and EMS on Seed Germination and Plant Survival of Pisum sativum L. and Lens culinaris. Medical Neo Botanica, 4 (1): 25 - 29

Kurniati, R. 2004. Induksi Keragaman Genetik Phalaenopsis hinamatsuri x Doritaenopsis Modern Beauty dan Phalaenopsis amabilis x Phalaenopsis tapei gold 'CS' dengan Menggunakan Iradiasi Sinar Gamma. Tesis. Institut Pertanian Bogor. Bogor

Lestari, E.G .2011. Peranan Zat Pengatur Tumbuh Dalam Perbanyakan Tanaman Melalui Kultur Jaringan. Jurnal Agro Biogen, 7 (1): 63-68

Luckey, T. 1998. Radiation hormesis: Biopositive effect of radiation. Radiation Science and Health, CRC Press. Boca Raton, Florida. USA.

Luckey, T. 2003. Radiation Hormesis Overview. RSO Magazine, 4: $19-36$
Lukanda, L.T., Mbuyi, A.K., Nkongolo, K.K.C., and Kizungu, R.V. 2013. Effect of gamma irradiation on morpho-agronomic characteristics of groundnut (Arachis hypogea L.). American Journal Plant Science, 4 (11): 2186-2192

Micke, A, and Donini. 1993. Induced mutation In M.D. Hayward, N.O. Bosemark, and I. Romagosa (Eds.) Plant Breeding Principles and Prospects. Chapman \& Hall. London.

Predieri, S. 2001. Mutation induction and tissue culture in improving fruits. Plant Cell, Tissue and Organ Culture, 64 (2): 185-210

Rosmala, A., Khumaida,N.,dan Sukma, D. 2015. Perubahan Morfologi dan Pertumbuhan Handeleum (Graphtophyllum pictumL. Griff) Akibat Iradiasi Sinar Gamma. Jurnal Agronomi Indonesia,43 (3): 235-241

Royani, J.l., A. Purwito, W. Sumaryono. 2012. Pengaruh Irradiasi Sinar Gamma Cobalt 60 terhadap Karakter Morfologi Tanaman Obat Sambiloto (Andrographis paniculata (Burm.f.) Wallich Ex Ness). Prosiding Seminar Nasional POKJANAS TOI XLII.hal. 63-76

Soeranto, H. 2003. Peranan Iptek Nuklir Dalam Pemuliaan Tanaman Untuk Mendukung Industri Pertanian. Prosiding Pertemuan dan Presentasi llimiah Peneiltian Dasar Ilmu Pengetahuan dan Teknologi Nuklir P3TM - BATAN Yogyakarta, 308 - 316

Sparrow, A, and Woodwell, G. 1962. Prediction of the sensitivity of plant to chronic gamma irradiation. Radiation Botany, 2(1): 9-12

Surya, M.I. 2009. Keanekaragaman dan potensi Rubus spp. koleksi Kebun Raya Cibodas. Warta Kebun Raya, 9(1): 21-26

Surya, M.I., Ismaini, L., Destri, dan Normasiwi, S. 2016. An effort of mutation breeding on wild raspberry (Rubus spp.) in Cibodas Botanical Garden.Biosaintifika, 8 (3): 331-335

Surya, M.I., Suhartati, S., Ismaini, L., Lusini, Y., Destri, Anggraeni, D., Normasiwi, S., Asni, N., dan Sidiq, M.A. 2018. Fruit Nutrients of Five Species of Wild Raspberries (Rubus spp.) from Indonesian Mountain's Forests. The Journal of Tropical Life Sciences, 8 (1): 75 - 80

USDA. 2014. National nutrient database for standard reference release 28. http://ndb.nal.usda.gov/. Accessed: February 7, 2016 Wattimena, G.A. 1992. Bioteknologi tanaman I. Pusat Antar Universitas Bioteknologi, Institut Pertanian Bogor. 455p

Yunita, R. 2009. Pemanfaatan Variasi Somaklonal dan Seleksi In Vitro dalam Perakitan Tanaman Tolerance Kamana Biotic. Jurnal Litbang Pertanian, 28 (4): 142-148

Zanzibar, M,dan Sudrajat, D.J. 2013. Prospek dan Aplikasi Teknologi Iradiasi Sinar Gamma untuk Perbaikan Mutu Benih dan Bibit Tanaman Mutan. Prosiding Seminar Teknologi Perbenihan, Silvikultur Dan Kelembagaan Dalam Peningkatan Produktivitas Hutan Dan Lahan. 1-13p 